Background: Cytogenetic investigations play an important role in the diagnosis of lymphomas. One of the recurrent aberrations in T-cell non-Hodgkin lymphoma (T-NHL) is a loss of the suppressor gene CDKN2A (9p21). The loss of this region is not seen in the karyotype; this deletion is submicroscopic in most cases.

Material and methods: We present the results of the status of $9 p 21$ deletion with the CDKN2A gene in 55 patients with cases of T-NHL, which were investigated in our laboratory in 2007-2010. We use FISH with a unique probe, CDKN2A/CEP9, for the 9p21 region on material obtained mostly by fine needle aspiration biopsy (FNAB) of lymph nodes or extranodal tumours, cerebrospinal, pleural and peritoneal fluids, or peripheral blood and bone marrow. Results: Deletion of 9p21 was found in $29 \%(n=55)$ of patients with T-NHL. Loss of CDKN2A was observed in 11 (55\%) out of 20 cases with T-LBL/ALL, in $2(33 \%)$ out of 6 with T-LGL and in $3(20 \%)$ out of 15 patients with peripheral T-cell lymphoma, not otherwise specified (PTCL-NOS). Patients with MF, SS, primary cutaneous peripheral T-cell lymphomas and other sporadic subtypes of peripheral T-cell lymphomas did not show deletion of this region. In studied lymphomas with deletion we observed a heterogeneous signal pattern in most cases (over $81 \%$ ). Analysis of the signal pattern of CDKN2A deletion showed clones with mono- and biallelic deletion in cells with variable ploidy. Probably, this phenomenon is related to concurrent incidence of cells which are in different stages of neoplastic transformation.

Key words: T-cell lymphoma, deletion of CDKN2A gene, monoallelic (heterozygous) deletion, biallelic (homozygous) deletion, heterogeneity of signal pattern, $\mathrm{FISH}$.

\section{Frequency of deletion of CDKN2A (9p21) gene in T-cell lymphomas in FISH analysis}

Anna Pastwińska ${ }^{1}$, Jolanta Rygier ${ }^{1}$, Renata Woroniecka ${ }^{1}$, Beata Grygalewicz, Paulina Krawczyk¹, Barbara Pieńkowska-Grela', Grzegorz Rymkiewicz², Magdalena Feliksbrot-Bratosiewicz ${ }^{2}$

${ }^{1}$ Cytogenetics Laboratory, M. Sklodowska-Curie Memorial Cancer Centre and Institute, Warsaw, Poland

2Flow Cytometry Laboratory, Department of Pathology, M. Sklodowska-Curie Memorial Cancer Centre and Institute, Warsaw, Poland

\section{Background}

Non-Hodgkin's lymphomas are characterized by clonal proliferation of cells, corresponding to distinct stages of differentiation of normal B- and T-lymphocytes and NK (natural killer) cells. T-cell lymphomas (12-15\%) are much rarer than B-cell lymphoproliferations (85-86\%), but NK-cell neoplasms are much more infrequent (2\%) [1-4]. The incidence of specific subtypes of T/NK-cell lymphomas varies depending on geographic region and race, and they comprise about 5\% of cases in Poland [5]. Approximately $75 \%$ of lymphomas diagnosed in Europe have nodal presentation. Due to the course of the disease we are able to distinguish low grade lymphomas (indolent), high grade (aggressive) and very aggressive lymphomas. Neoplastic proliferations of precursor cells (lymphoblastic) are usually more aggressive than those derived from mature cells (peripheral) [6].

Correct diagnosis of $\mathrm{NHL}$ is often difficult in routine histopathological and immunohistochemical investigations and requires application of flow cytometry, cytogenetic and molecular studies. Cytogenetic investigations, which comprise two techniques - analysis of G-banded karyotype and use of fluorescent in situ hybridization (FISH) - and molecular methods with polymerase chain reaction (PCR) currently play an important role in the integrated $\mathrm{NHL}$ diagnostics. They allow evaluation of specific chromosomal aberrations, determining the presence of fusion genes and determining the clonality of $B$ and $T$ cells (IGH and TCR gene rearrangement). Cytogenetic and molecular studies are an established, complementary method for the diagnosis of B-cell lymphomas, and are required e.g. to confirm a final diagnosis of Burkitt lymphoma and B-cell lymphoma, unclassifiable, with features intermediate between diffuse large B-cell lymphoma and Burkitt lymphoma. In T-NHLs these studies are performed infrequently, usually in mycosis fungoides (MF) and Sezary syndrome (SS), due to increased incidence of these lymphomas and ease of cytogenetic investigation on peripheral blood and bone marrow. In the group of primary cutaneous peripheral T-cell lymphomas, molecular assessment of clonality of TCR gene rearrangement is a diagnostic criterion in accordance with the requirements of the WHO-EORTC classification [7-10]. However, nodal and extranodal T-NHL are infrequently subjected to routine evaluation of TCR gene rearrangement and cytogenetic investigation. This is due to the rarity of these lymphomas, limitations in collecting such material for the cytogenetic tests and obtaining a sufficient number of cell divisions in vitro culture or unsatisfactory quality of the metaphases.

One of the recurrent aberrations in T-NHL is the loss of part of the short arm of chromosome 9. On this chromosome in band 9p21 there are at least two tumour suppressor genes, CDKN2A and CDKN2B, which belong to the family of inhibitors of cyclin-dependent kinases, which control cell transition 
from G1 to S phase of the cell cycle. The two genes occupy the same region on chromosome 9 , but their products are encoded by alternative reading frames. The CDKN2A gene encodes two proteins, $\mathrm{p} 14$ and $\mathrm{p} 16$, and the CDKN2B gene p15 protein. The CDKN2A-2B region is often deleted in human solid tumours and haematological malignancies, and there is also described hypermethylation of the promoter region, which causes inactivation of the gene [11-20]. Loss of this region is rarely seen in the karyotype; most patients have submicroscopic deletions. There are a lot of publications about the deletion of the 9p21 region in children with ALL (acute lymphoblastic leukaemia). In the case of adult lymphomas, such publications are rare, especially in the field of T-NHL. Generally, the CDKN2A gene deletions occur infrequently and affect $0-15 \%$ of NHL cases [11, 12 , 21-25]. However, in advanced stages of mantle cell lymphoma (MCL) or aggressive T-NHL the incidence is increased to $43 \%$ [23-28]. These results are not fully satisfactory because of the limited number of tested patients. Because of the low incidence of T-NHL available, overviews of single cases still do not permit the formulation of clear conclusions.

In this study we present the results of the analysis of the deletion status of the 9p21 region with the CDKN2A gene in a group of 55 patients with T-NHL, investigated in our laboratory by FISH.

\section{Material and methods}

In this study we analysed material from 55 patients with T-NHL diagnosed (by cytometry or histopathology) in Warsaw Oncology Centre and Institute in 2007-2010. In this group of patients T-LBL/ALL (T lymphoblastic lymphoma/leukaemia) was diagnosed in 20 patients (16 T-LBL, 4 T-ALL), PTCL-NOS (peripheral T-cell lymphoma, not otherwise specified) in 15 patients and T-LGL (T-cell large granular lymphocytic leukaemia) in 6 patients. MF, SS and cutaneous lymphomas were diagnosed in 9 patients, other sporadic subtypes of T-NHL (extranodal NK/T-cell lymphoma, nasal type; hepatosplenic T-cell lymphoma; CD56+ primary

Table 1. Percentage of 9p21 deletion types in 55 cases of T-cell lymphomas

\begin{tabular}{|c|c|c|c|c|}
\hline Diagnosis & $\begin{array}{l}\text { 9p21 deletion } \\
\text { (total) }\end{array}$ & $\begin{array}{c}\text { Monoallelic } \\
\text { deletion }\end{array}$ & $\begin{array}{l}\text { Biallelic } \\
\text { deletion }\end{array}$ & $\begin{array}{l}\text { Mixed } \\
\text { deletion } \\
\text { (mono-and } \\
\text { biallelic) }\end{array}$ \\
\hline \multicolumn{5}{|c|}{ Lymphomas } \\
\hline $\begin{array}{l}\text { T-ALL/T-LBL } \\
(n=20)\end{array}$ & $55 \%(n=11)$ & $30 \%(n=6)$ & $10 \%(n=2)$ & $15 \%(n=3)$ \\
\hline $\begin{array}{l}\mathrm{PTCL} \\
(n=15)\end{array}$ & $20 \%(n=3)$ & $20 \%(n=3)$ & - & - \\
\hline $\begin{array}{l}\text { T-LGL } \\
(n=6)\end{array}$ & $33 \%(n=2)$ & - & - & $33 \%(n=2)$ \\
\hline $\begin{array}{l}\text { MF/SS/ } \\
\text { Cutaneous } \\
\text { lymphomas } \\
(n=9)\end{array}$ & 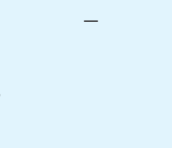 & - & - & - \\
\hline $\begin{array}{l}\text { Other } \\
(n=5)\end{array}$ & - & - & - & - \\
\hline
\end{tabular}

gastrointestinal T-cell lymphoma; peripheral T-cell leukaemia CD4+ unclassifiable; T-NHL, unspecified?) in 5 persons. In our study we used the following diagnostic material: cell suspension obtained by FNAB of lymph nodes or tumours $(n=30)$, cerebrospinal fluid $(n=1)$, pleural fluid $(n=2)$, peritoneal fluid $(n=3)$, peripheral blood (PB) $(n=14)$ and bone marrow $(\mathrm{BM})(n=5)$. All cytogenetically analysed samples had the presence of T-NHL cells confirmed by flow cytometry.

The cell suspension aspirated by FNAB was transported to Eagle medium with antibiotics and anticoagulant and subsequently subjected to short-term in vitro culture: $24 \mathrm{~h}$ culture without stimulators and $72 \mathrm{~h}$ culture with LF-7 mitogen (unpurified lectin from Phaseolus vulgaris) or fixed directly after collecting. After fixation of materials by the standard method, preparations were made, which were then tested by FISH. We used commercially available LSI CDKN2A/CEP9 (Vysis, Abbott) for the 9p21 region with the CDKN2A gene, where the 9p21 region is labelled with red fluorochrome, while the centromere of chromosome 9 is labelled green. At least 200 interphase nuclei were analysed (in two cases, only 100 cells) in searching for the deletion, and the results are described according to the International System for Human Cytogenetic Nomenclature (ISCN) [29]. The cut-off for the 9p21 deletion was set at 10\% in our laboratory.

\section{Results}

In all 55 cases of T-NHL investigations for CDKN2A deletion were performed and the results are presented in Tables 1 and 2. Deletion of the 9p21 region was found in 29\% ( $n=16 / 55)$ of patients. Among the 20 individuals with a T-LBL/ALL diagnosis the deletion was observed in 11 (55\%), whereas in the 6 patients with T-LGL it was observed in 2 (33\%). Of the 15 patients with PTCL-NOS the deletion was noted in 3 cases (20\%). Material of patients with a diagnosis MF, SS, cutaneous lymphomas and other sporadic subtypes of T-NHL demonstrated no 9p21 deletion in any case. In the T-NHL group there were found two types of deletion of the CDKN2A gene: monoallelic (heterozygous) characterized by loss of one copy of the gene, or biallelic (homozygous), where both copies are lost. In some of the analysed T-NHL cases the concurrent presence of mono- and biallelic clones was found. In the group of 20 patients with T-LBL/ALL, in 6 a signal pattern indicating monoallelic deletion (30\%) was observed, in 2 biallelic deletion (10\%), and in 3 there appeared clones with the loss of either one or two copies of the 9p21 region (15\%). Monoallelic deletion was observed in 3 patients (20\%) with PTCL-NOS, whereas individuals with CDKN2A deletion with diagnosis of T-LGL were present in 2 clones: with loss of one or two copies of the gene.

A detailed analysis of the signal pattern in the cases with CDKN2A gene deletion showed variability of the number and proportion of distinct signals, labelling the 9p21 region (CDKN2A gene, red signal - R) and the centromere of chromosome 9 (green signal - G) (Table 1, Fig. 1, Fig. 2). Heterogeneity of the signal pattern consisting in the occurrence of several clones with a distinct signal pattern in a single 
case was demonstrated in 13 patients. In the 9 T-LBL/ALL cases with monoallelic deletion in 3 there was found the presence of concurrent clones with the 1 R1G pattern, indicating monosomy 9, and with the OR2G/OR1G pattern with two or one copy of chromosome 9 without the 9 p21 region. In one case of this group a clone with the 2R4G pattern was observed, with 4 copies of chromosome 9 , two of which carried a deletion. Another case with the sole presence of cells bearing biallelic deletion demonstrated loss of all copies of CDKN2A, both in diploid (two copies of centromere 9) and polyploid cells (3 to 5 copies of centromere 9).

In one patient with PTCL-NOS with monoallelic deletion two parallel clones with 1 R2G and 2 R3G signal pattern, respectively, were found, which indicates the presence of 2 and 3 copies of chromosome 9 , one of which carries a deletion. Among the 5 cases showing simultaneously both types of deletion (coexisting clones with loss of one or two 9p21 clones) 3 cases were found with concurrent monosomy 9 (loss of one signal of centromere 9): 1R1G and OR1G clones.

In the T-NHL group the frequency of deletion of the 9p21 region, depending on the type of material, was also examined. The loss of CDKN2A was found in $27 \%(8 / 30)$ of tested materials obtained by FNAB and in both (100\%) cases of pleural fluid. In the peritoneal fluid deletion was observed in 33\% (1/3), and in BM in 60\% (3/5). In PB loss of the 9p21 region was found only in 2 of 14 cases (14\%). There were no deletions in the analysed cerebrospinal fluid. The total frequency of deletion in T-NHL was 31\% (11/35) in the analysed materials.

\section{Discussion}

As reported by various authors, the frequency of CDKN2A deletion or mutations in non-Hodgkin's lymphoma ranges from 0 to $15 \%$ [21, 23, 25]. By contrast, in paediatric acute lymphoblastic leukaemia deletion of the CDKN2A tumour suppressor gene is observed much more frequently, in as many as $80 \%$ of cases (50-80\% T-ALL and 5-20\% B-ALL) [30-35].

In our group of patients with T-NHL a deletion of the 9p21 region was found in $29 \%$ of all cases: more often in T-LBL/ALL (55\%, 11 cases) and T-LGL (33\%, 2 cases) than in PTCL-NOS (20\%, 3 cases). However, depending on the type of material, the frequency of deletion determined for tumour cells of the lymphatic system was 31\%. This is similar to the percentage of the total value of $29 \%$ of cases with loss of the CDKN2A gene. The results obtained in our laboratory indicate a higher percentage of cases with CDKN2A deletion than those reported in other publications. Previous data concerning the loss of 9p21 in adult T-NHL are not sufficient for a complete comparative analysis. Information from single published studies is incomplete: Stranks et al. [23] investigated a small group of cases and found the deletion of CDKN2A in 2 of 6 patients with T-LBL (33\%), and its absence in the group with T-PLL (T-cell prolymphocytic leukaemia) and T-LGL. Similar results were obtained by Otsuki et al. [22], who found no loss of tumour suppressor gene in T-PLL and PTCL-NOS, but it was present in 8 of 23 cases of T-LGL (35\%). Different groups investigating the presence of deletion of the 9p21 region in PTCL-NOS obtained varying results: from its absence [22] to 19\% [36], 25\% [37] and 31\% [38]. The larg-
Table 2. Analysis of pattern of hybridization of $9 p 21$ region with CDKN2A gene and chromosome 9 centromere in cells of 16 cases with T-cell lymphomas

\begin{tabular}{|c|c|c|c|c|}
\hline \multirow[t]{2}{*}{ No. } & \multicolumn{2}{|c|}{ Signal pattern } & \multirow{2}{*}{$\begin{array}{l}\text { Number of } \\
\text { copies } \\
\text { of chr. } 9\end{array}$} & \multirow[t]{2}{*}{ Diagnosis } \\
\hline & $\begin{array}{c}\text { Monoallelic } \\
\text { deletion }\end{array}$ & $\begin{array}{l}\text { Biallelic } \\
\text { deletion }\end{array}$ & & \\
\hline \multirow[t]{2}{*}{1.} & $1 R 2 G$ & & 2 & T-LBL \\
\hline & 2R4G & & 4 & \\
\hline \multirow[t]{2}{*}{2.} & $1 R 2 G$ & OR2G & 2 & $T-L B L$ \\
\hline & & OR1G & 1 & \\
\hline 3. & $1 \mathrm{R} 2 \mathrm{G}$ & OR2G & 2 & T-LBL \\
\hline 4. & $1 R 2 G$ & & 2 & T-LBL \\
\hline 5. & $1 \mathrm{R} 1 \mathrm{G}$ & OR1G & 1 & T-LBL \\
\hline 6. & $1 \mathrm{R} 2 \mathrm{G}$ & & 2 & T-LBL \\
\hline \multirow[t]{2}{*}{7.} & $1 \mathrm{R} 2 \mathrm{G}$ & & 2 & T-LBL \\
\hline & 1R1G & & 1 & \\
\hline \multirow[t]{2}{*}{8.} & $1 \mathrm{R} 2 \mathrm{G}$ & & 2 & $T-L B L$ \\
\hline & 1R1G & & 1 & \\
\hline \multirow[t]{4}{*}{9.} & & OR2G & 2 & T-LBL \\
\hline & & OR3G & 3 & \\
\hline & & OR4G & 4 & \\
\hline & & OR5G & 5 & \\
\hline \multirow[t]{2}{*}{10.} & $1 \mathrm{R} 2 \mathrm{G}$ & & 2 & T-ALL \\
\hline & 1R1G & & 1 & \\
\hline \multirow[t]{2}{*}{11.} & & OR2G & 2 & T-ALL \\
\hline & & OR1G & 1 & \\
\hline 12. & $1 \mathrm{R} 2 \mathrm{G}$ & & 2 & PTCL-NOS \\
\hline \multirow[t]{2}{*}{13.} & $1 \mathrm{R} 2 \mathrm{G}$ & & 2 & PTCL-NOS \\
\hline & 2R3G & & 3 & \\
\hline \multirow[t]{2}{*}{14.} & $1 \mathrm{R} 2 \mathrm{G}$ & & 2 & PTCL-NOS \\
\hline & 1R1G & & 1 & \\
\hline \multirow[t]{2}{*}{15.} & $1 \mathrm{R} 2 \mathrm{G}$ & OR2G & 2 & T-LGL \\
\hline & 1R1G & & 1 & \\
\hline 16. & $1 \mathrm{R} 2 \mathrm{G}$ & OR2G & 2 & T-LGL \\
\hline
\end{tabular}

Abbreviations: $R$-red signal; $G$ - green signal; $0,1, \ldots, 5$ - number of signals in cell.

er proportion of patients with CDKN2A deletion in this study may be due to the high percentage of T-LBL in our material and the use of different biological material for cytogenetic analysis than in other publications.

CDKN2A deletion was not found in any of the 9 cases with cutaneous T-NHL that we studied (including MF and SS). A small number of reports of 9p21 deletion in this group of lymphomas differ from the results obtained in our laboratory. Data show $25 \%$ to $57 \%$ of cases of MF/SS with CDKN2A deletion $[14,18]$. Also other investigators reported lack of expression of p16 in cell lines derived from MF and SS and in the blood of patients with SS [15]. Lack of the reported deletions in our group of MF/SS patients could be caused by either the small number of analysed cases or lack of more advanced cases in this group, especially in MF with minimal PB involvement or non-optimal selection of material for the study (cell homogenates from infiltration of skin would be optimal). 

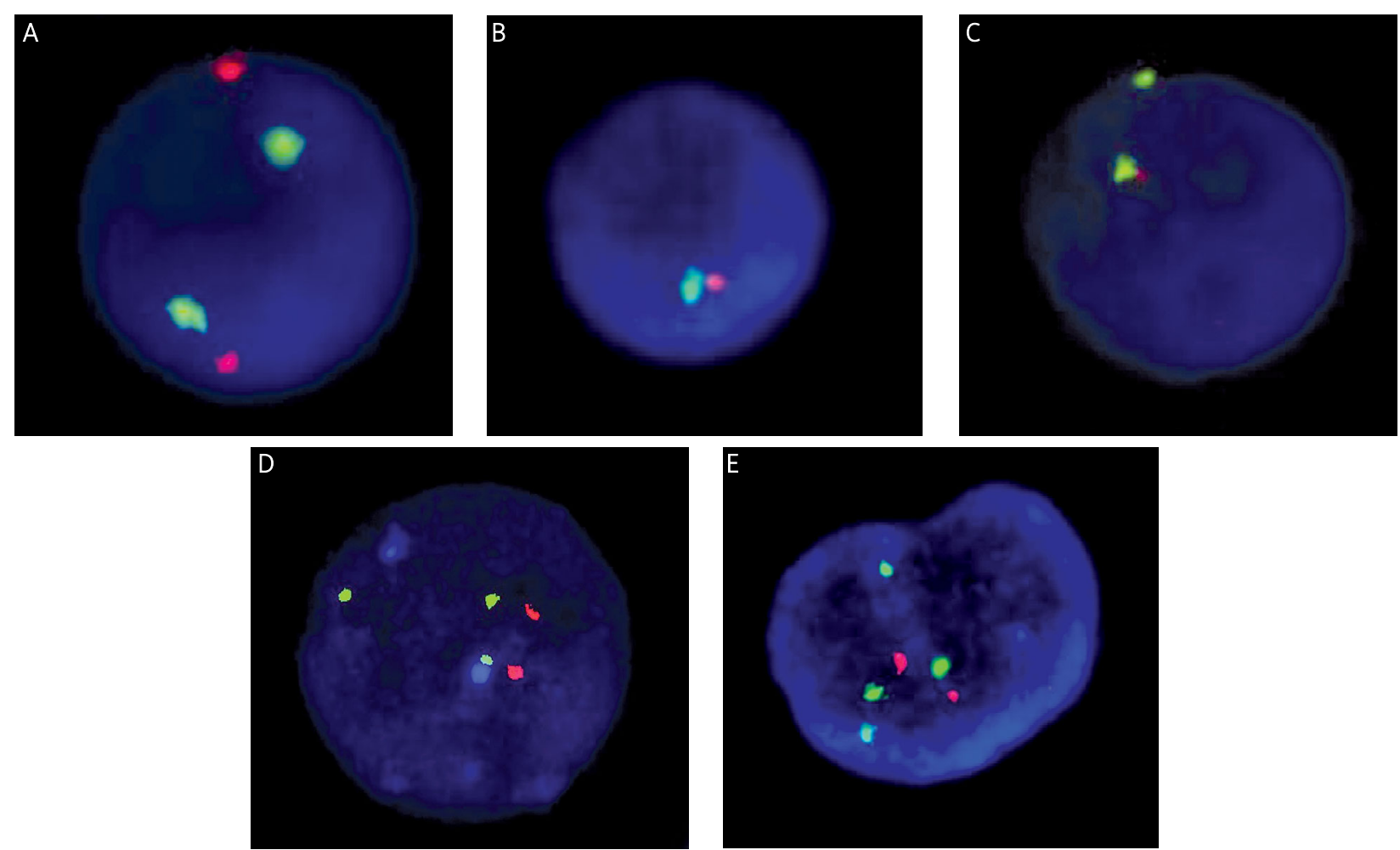

Fig. 1. Monoallelic deletions of CDKN2A - signal pattern of hybridization with CDKN2A/CEP9 probe in near-diploid cells (B, C) and in polyploid cells $(D, E)$

Red signal - 9p21 region with CDKN2A gene; green signal - CEP9, chromosome 9 centromere.

A - normal cell: two signals CDKN2A and CEP9

B - monosomy 9: 1 signal CDKN2A and CEP9, lack of CDKN2A and CEP9 signals

C - CDKN2A deletion in 2n cell: 1 CDKN2A signal and 2 CEP9 signals

D - CDKN2A deletion in 3n cell: 2 CDKN2A signals and 3 CEP9 signals

$\mathrm{E}-$ CDKN2A deletion in 4n cell: 2 CDKN2A signals and 4 CEP9 signals
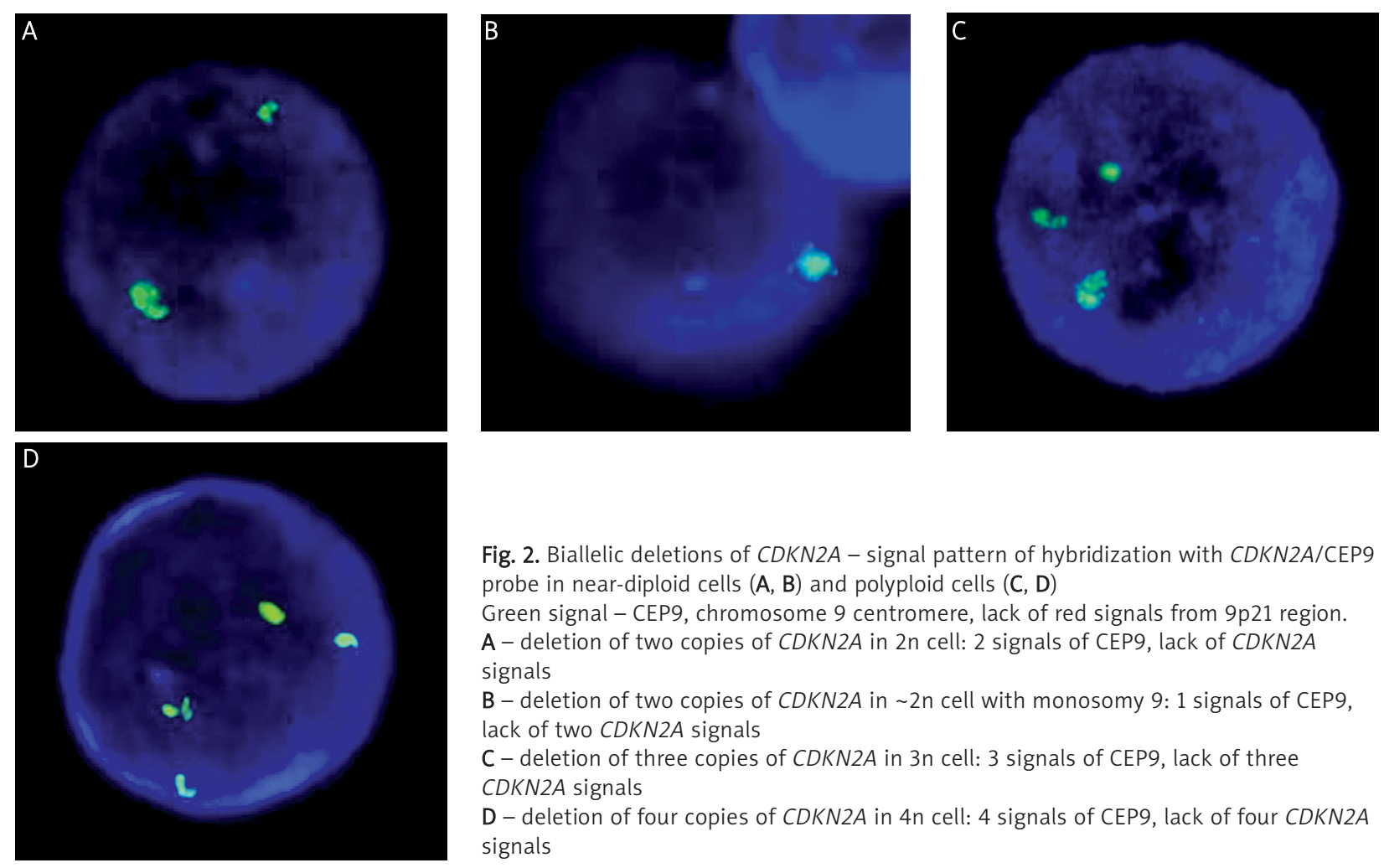

Fig. 2. Biallelic deletions of CDKN2A - signal pattern of hybridization with CDKN2A/CEP9 probe in near-diploid cells (A, B) and polyploid cells (C, D)

Green signal - CEP9, chromosome 9 centromere, lack of red signals from 9p21 region.

A - deletion of two copies of CDKN2A in $2 \mathrm{n}$ cell: 2 signals of CEP9, lack of CDKN2A signals

B - deletion of two copies of CDKN2A in 2n cell with monosomy 9: 1 signals of CEP9, lack of two CDKN2A signals

$\mathrm{C}$ - deletion of three copies of CDKN2A in $3 \mathrm{n}$ cell: 3 signals of CEP9, lack of three CDKN2A signals

D - deletion of four copies of CDKN2A in 4 n cell: 4 signals of CEP9, lack of four CDKN2A signals 
Previous published results of studies of the status of 9p21 deletions showed a certain regularity. In cases of lymphoma type MF/SS polyclonality is usually demonstrated: simultaneous occurrence of both types of deletion (mono- and biallelic) and additionally 2-3 clones with different signal pattern. On the other hand, in B- and T-ALL only one type of deletion is almost always present [16-19, 30, 31, 33, 34]. In our study, regardless of the subtype of lymphoma, a heterogeneous signal pattern was found in the majority of all cases with a deletion (in over $81 \%$ of cases). This results from the simultaneous occurrence of several clones in each patient. These clones differ in the deletion pattern (mono- and biallelic) and in the copy number of chromosome 9 . The analysis showed occurrence of either monosomy 9, which accompanies the presence of CDKN2A deletion, or multiplication of the copy number of chromosome 9 with deletion, probably as a result of polyploidization of cells $(3 n, 4 n, 5 n)$. Similar results were obtained by Laharanne et al. [18], who analysed the profile of CDKN2A deletion in aggressive, cutaneous T-cell lymphomas, and by Leblanc et al. [13], studying the loss of 9 p21 in lymphoid proliferations. This phenomenon has not yet been described in publications concerning lymphomas from PTCLNOS and T-LGL subtypes. The presence of a heterogeneous signal pattern in a group of our patients could be caused by the occurrence in one patient of cell clones which are at different stages of neoplastic transformation, which is a manifestation of ongoing progression. In accordance with the results obtained in adult T-NHL sequential development of aberrations associated with chromosome 9 seems probable. Monoallelic 9p21 deletion seems to precede the loss of the second copy of the CDKN2A gene. Changes in the number of chromosome 9 - losses (monosomies, nullosomies) or multiplications (tri-, tetra-, pentasomies) - are probably associated with further progression of neoplasm.

In the literature data concerning paediatric T-ALL monoand biallelic deletions predominate. Homozygous deletions are definitely predominant. However, one or the other type of deletion is, in this group of leukaemia patients, associated with a worse prognosis [30, 33, 34, 39]. A small number of studies performed on adult lymphomas, especially B-cell type, did not show the status of mono- and biallelic deletion, although they revealed that 9p21 deletions are associated with primary aggressive and transformed lymphomas, but are rarely found in indolent lymphomas [18, $23,24,27,28,40]$. These deletions are also the cause of resistance to chemotherapy [18]. The analysis of the signal pattern of the CDKN2A deletion revealed a complex scheme of mono- and biallelic deletions in our T-NHL group. But still the limited range of data allows only for initial speculations concerning the mechanism of the described phenomenon.

\section{Summary}

Our study allowed us to determine cases of T-NHL with a CDKN2A deletion. We also found that the heterogeneity of the signal pattern in neoplastic cells that we tested could be associated with simultaneous occurrence of cell clones at different stages of neoplastic transformation. The results encourage a study of a larger group of patients with different subtypes of T-NHL to determine the signal pattern and type of CDKN2A deletion, so that in the future the prognostic significance of this change can be evaluated. Perhaps the analysis of a larger population of adult T-cell lymphomas will allow us to determine the specific group of tumours with more frequent deletion. The issue of the impact of the deletion on the course of the disease and survival of patients with T-cell lymphomas requires a longer period of observation, and further studies by us.

\section{References}

1. Hematologia dla studentów i lekarzy. Robak T (red.). Uniwersytet Medyczny w Łodzi, Łódź 2007.

2. Podstawy Hematologii. Dmoszyńska A, Robak T (red.). Wydawnictwo Czelej, Lublin 2003.

3. Warzocha K, Krykowski E, Robak T. Klasyfikacja i leczenie chłoniaków złośliwych T-komórkowych. Onkol Pol 2000; 3: 137-47.

4. Provan D, Singer C, Baglin T, Lilleyman J. Hematologia kliniczna. Hołowiecki J (red.). Wydawnictwo Lekarskie PZWL, Warszawa 2008.

5. Gałązka K, Szpor J, Maryniak R, Olszewski W, Mioduszewska O, Stachura J. Incidence of lymphoma in Poland. The National Register Data for 2006. Pol J Pathol 2007; 58: 199-206.

6. WHO Classification of Tumours of Heamatopoietic and Lymphoid Tissues; Swerdlow SH, Campo E, Harris NL, Jaffe ES, Pileri SA, Stein H, Thiele J, Vardiman JW (eds.). IARC, Lyon 2008.

7. Sokołowska-Wojdyło M, Roszkiewicz J. Pierwotne chłoniaki skóry. Wydawnictwo Czelej, Lublin 2008.

8. Sokołowska-Wojdyło M, Nedoszytko B, Zabłotna M, Gleń J, Placek W. Diagnostyka genetyczna chłoniaków T-komórkowych pierwotnie wywodzących się ze skóry. Część I: Zastosowanie analizy rearanżacji genu receptora TCR w diagnostyce chłoniaków pierwotnie skórnych z komórek T. Post Dermatol Alergol 2007; 24: 151-6.

9. Nedoszytko B, Sokołowska-Wojdyło M, , Zabłotna M, Gleń J, Roszkiewicz J. Diagnostyka genetyczna chłoniaków T-komórkowych pierwotnie wywodzących się ze skóry. Część II: Znaczenie aberracji chromosomowych w diagnostyce i patogenezie chłoniaków T-komórkowych. Post Dermatol Alergol 2007; 24: 157-64.

10. Sokołowska-Wojdyło M, Nedoszytko B, Gleń J, Zabłotna M, Placek W, Silny W, Wąsik A, Roszkiewicz J. Diagnostyka genetyczna chłoniaków T-komórkowych pierwotnie wywodzących się ze skóry. Część III: Porównanie częstości występowania nieprawidłowych klinów komórkowych w chłoniakach T-komórkowych skóry analizowanych za pomoca badania molekularnego z zastosowaniem analizy rearanżacji genów TCR $\gamma$ i metody cytogenetycznej. Post Dermatol Alergol 2007; 24: 165-70.

11. Ogawa S, Hangaishi A, Miyawaki S, et al. Loss of the cyclin-dependent kinase 4-inhibitor (p16; MTS1) gene is frequent in and highly specific to lymphoid tumors in primary human hematopoietic malignancies. Blood 1995; 86: 1548-56.

12. Hangaishi A, Ogawa S, Imamura N, et al. Inactivation of multiple tumor-suppressor genes involved in negative regulation of cell cycle, MTS1/p16INK4A/CDKN2, MTS2/p16INK4B, p53, and Rb genes in primary lymphoid malignancies. Blood 1996; 87: 4949-58.

13. Leblanc T, Derre J, Flexor M, Le Coniat M, Leroux D, Rimokh R, Larsen C-J, Berger R. FISH analysis of translocations involving the short arm of chromosome 9 in lymphoid malignancies. Genes Chromosomes Cancer 1997; 19: 273-7.

14. Scarisbrick JJ, Woolford AJ, Calonje E, Photiou A, Ferreira S, Orchard G, Russell-Jones R, Whittaker SJ. Frequent abnormalities of the P15 and P16 genes in Mycosis Fungoides and Sezary Syndrome. J Invest Dermatol 2002; 118: 493-9.

15. Zhang C, Toulev A, Kamarashev J, Qin J-Z, Dummer R, Döbbeling U. Consequences of p16 tumor suppressor gene inactivation in mycosis fungoides and Sézary syndrome and role of the bmi-1 and ras oncogenes in disease progression. Human Pathology 2007; 38: 995-1002.

16. Kim M, Yim S-H, Cho N-S, et al. Homozygous deletion of CDKN2A (p16, p14) and CDKN2A (p15) genes is a poor prognostic factor in adult but not in childhood B-lineage acute lymphoblastic leukemia: 
a comparative study deletion and hypermethylation study. Cancer Genet Cytogenet 2009; 195: 59-65.

17. Schiffman JD, Wang Y, McPherson LA, et al. Molecular inversion probes reveal patterns of 9p21 deletion and copy number aberrations in childhood leukemia. Cancer Genet Cytogenet 2009; 193: 9-18.

18. Laharanne E, Chevret E, Idrissi Y, et al. CDKN2A/CDKN2B deletion defines an agressive subset of cutaneous T-cell lymphoma. Modern Pathology 2010; 23: 547-58.

19. Gorello P, La Starza R, Varasano E, et al. Combined interphase fluorescence in situ hybridization elucidates the genetic heterogeneity of T-cell acute lymphoblastic leukemia in adults. Haematologica 2010; 95: 79-86.

20. Rodrigues EF, Santos-Reboucas CB, Pimentel GMM, et al. Epigene tic alterations of $\mathrm{p} 15 \mathrm{INK} 4 \mathrm{~B}$ and $\mathrm{p} 16 \mathrm{INK} 4 \mathrm{~A}$ genes in pediatric primary myelodysplastic syndrome. Leukemia Lymphoma 2010; 51: 1887-94.

21. Koduru PRK, Zarivala M, Soni M, Gong JZ, Xiong Y, Broome JD. Deletion of cyclin-dependent kinase 4 inhibitor genes P15 and P16 in non-Hodgkin's lymphomas. Blood 1995; 86: 2900-05.

22. Otsuki T, Clark HM, Wellmann A, Jaffe ES, Raffeld M. Involvement of CDKN2 (p16INK4A/MTS1) and p15INK4B/MTS2 in human leukemias and lymphomas. Cancer Res 1995; 55: 1436-40.

23. Stranks G, Height SE, Mitchell P, et al. Deletion and rearrangement of CDKN2 in lymphoid malignancy. Blood 1995; 85: 893-901.

24. Pinyol M, Hernandez L, Cazorla M, et al. Deletion and loss of expression of P16INK4a and P21Waf1 genes are associated with aggressive variants of mantle cell lymphomas. Blood 1997; 89: 272-80.

25. Pinyol M, Cobo F, Bea S, et al. p16INK4a gene inactivation by dele tions, mutations and hypermetylation is associated with transformed and aggressive variants of non-Hodgkin's lymphomas. Blood 1998; 91: 2977-84.

26. Bentz M, Plesch A, Bullinger L, et al. t(11;14)-positive mantle cell lymphoma exhibit complex karyotypes and share similarities with B-cell chronic lymphocytic leukemia. Genes Chromosomes Cancer 2000; 27: 285-94.

27. Kohlhammer H, Schwaenen C, Wessendorf S, et al. Genomic DNA-chip hybridization in t(11;14)-positive mantle cell lymphomas show a high frequency of aberrations and allows a refined characterization of consensus regions. Blood 2004; 104: 795-801.

28. Rubio-Moscardo F, Climent J, Siebert R, et al. Mantle-cell lymphoma genotypes identified with CGH to BAC microarrays define a leu kemic subgroup of disease and predict patient outcome. Blood 2005; 105: 4445-54

29. An International System for Human Cytogenetic Nomenclature (2009). Schaffer LG, Slovak ML, Campbell LJ (eds.). S. Kargel, Basel 2009

30. Okuda T, Shurtleff SA, Valentine MB, et al. Frequent deletion of p16INK4a/MTS1 and p15INK4b/MTS2 in pediatric acute lymphoblastic leukemia. Blood 1995; 85: 2321-30.

32. Faienza MF, Ragione FD, Basso G, Coppola B, del Giudice EM, Schet tini F, Iolascon A. p16INK4a gene homozygous deletions in human acute leukaemias with alterations of chromosome 9. Br J Haematol 1996; 93: 632-6.

32. Batova A, Diccianni MB, Yu JC, Nobori T, Link MP, Pullen J, Yu AL. Frequent and selective methylation of p15 and deletion of both p15 and p16 in T-cell acute lymphoblastic leukemia. Cancer Res 1997 57: 832-6.

33. Kees U, Burton PR, Lu C, Baker DL. Homozygous deletion of the p16/MTS1 gene in pediatric acute lymphoblastic leukemia is associated with unfavorable clinical outcome. Blood 1997; 89: 4161-6.

34. Einsiedel HG, TaubeT, Hartmann R, Wellmann S, Seifert G, Henze $\mathrm{G}$, Seeger K. Deletion analysis of p16INKa and p15INK4b in relapsed childhood acute lymphoblastic leukemia. Blood 2002; 99: 4629-31.

35. Strefford JC, Worley H, Barber K, et al. Genome complexity in acute lymphoblastic leukemia is revealed by array-based comparative genomic hybridization. Oncogene 2007; 26: 4306-18.

36. Leptretre S, Buchonet G, Stamatoullas A, et al. Chromosome abnormalities in peripheral T-cell lymphoma. Cancer Genet Cytogenet 2000; 117: 71-9.

37. Thorns C, Bastian B, Pinkel D, et al. Chromosomal aberrations in angioimmunoblastic T-cell lymphoma and peripheral T-cell lym- phoma unspecified: a matrix-based CGH approach. Genes Chromosomes Cancer 2007; 46: 37-44

38. Zettl A, Rüdiger T, Konrad M-A, Chott A, Simonitsch-Klupp H, Sonnen R, Müller-Hermelink HK, Ott G. Genomic profiling of peripheral T-cell lymphoma, unspecified and anaplastic large T-cell lymphoma delineates novel recurrent chromosomal alterations. Am J Pathol 2004; 164: 1837-48.

39. Fizzotti M, Cimino G, Pisegna S, Alimena G, Quartarone C, MandelliF, Pelici PG, Coco FL. Detection of homozygous deletions of the cyclin-dependent kinase 4 inhibitor (p16) gene in acute lymphoblastic leukemia and association with adverse prognostic features. Blood 1995; 85: 2685-90.

40. Salaverria I, Zettl A, Bea S, Moreno V, et al. Specific secondary genetic alteration in mantle cell lymphoma provide prognostic information independent of the gene expression-based proliferation signature. J Clin Oncol 2007; 25: 1216-22.

\section{Address for correspondence}

\section{Anna Pastwińska}

Cytogenetics Laboratory

M. Sklodowska-Curie Memorial Cancer Centre and Institute

K. W. Roentgena 5

02-781 Warsaw, Poland

tel. +48225462649

e-mail: apastwinska@gmail.com 